\title{
THE PERFORMANCE OF HANDLOOM WEAVERS IN CHITTOOR DISTRICT OF ANDHRA PRADESH - A STUDY
}

\section{Dr. Thapai Ananda* Dr. G. Prathap}

\author{
Post-Doctoral Fellow, Department of Economics, Sri Venkateswara \\ University, Tirupati-517502, Andhra Pradesh. ${ }^{*}$ Corresponding Author \\ Academic Consultant, Department of Economics, Sri Venkateswara \\ University, Tirupati-517502, Andhra Pradesh.
}

ABSTRACT Indian economic development has to be viewed in the light of the socio-economic factors, preservation of the traditional skills of the people and the use of the available resources. Handlooms have a great potential in this regard as they hold the key not only for sustaining the existing craft persons but also for providing gainful employment, both full-time and part-time, to increasingly larger sections of the economically poor and dispossessed weavers. Village and cottage industries to which the handloom industry belongs are oriented towards balanced socio-economic development of our country owing to the built-in mechanism that encourages weavers and craftsmen to seek an honorable place in the society. He advances raw materials and also cash, pays wages to the weavers on the condition that the weavers should supply him fabrics of a particular design. Weaving may be done on the looms owned and installed by the master weaver at his place or at the residence of the weaver or on the looms owned by the weaver and installed in his home. There is another class of master weavers, who can strictly be called middlemen, as they do not engage themselves in weaving, but have concentrated more on supplying of yarn and cash and marketing of cloth. The cost of inputs has been increased from $2014-15$ to 2007-2008 regardless of number of looms. Moreover, higher the number of looms higher is the expenditure towards the cost of inputs. The ' $F$ ' value is significant at 1 per cent level and confirmed that there are variations in the cost of inputs among the respondents of varied number of looms. The net income of the respondents of 1-4 looms and 10 and above has gradually increased, but the income is low for respondents of 4-10 looms in 2017-2018 owing to their dependency even on some other subsidiary activities which are more fetching. The income has gradually increased and higher the number of looms higher is net income.

\section{KEYWORDS : Handloom - Employment - Income - Weavers - Textile}

\section{INTRODUCTION}

Handloom industry in India is an ancient cottage industry with a decentralized set up. The industry is an age old source of livelihood for millions of people in the country. About 10 million people directly depend on the industry to eke out their livelihood, while zillions of people depend upon subsidiary occupations connected with the handloom industry. The share of employment provided by the handloom industry in the total decentralized sector is about 5.5 per cent. Thus, the industry constitutes one of the major sectors employing the largest number of persons next only to agriculture. In regard to production, industry is meeting one-third of the total cloth requirements of the masses in the country.

Handloom industry is perhaps the most important one among the hundreds of small scale and cottage arts and crafts that have survived by the present day in India. It is remarkable that in some cases it has been wiped out in most of the countries where modern textile industry has been established. But still it occupies a strategic position in India's socio-economic set up. The industry is not only ancient but its change is unique, in the sense, that in no other country in the world, where hand weaving is vogue on such a nationwide basis. And no where else could the hand loom industry so valiantly withstand the on-slaughter of and stiff competition from the giant textile machines as in India.

Indian economic development has to be viewed in the light of the socio-economic factors, preservation of the traditional skills of the people and the use of the available resources. Handlooms have a great potential in this regard as they hold the key not only for sustaining the existing craft persons but also for providing gainful employment, both full-time and part-time, to increasingly larger sections of the economically poor and dispossessed weavers. Village and cottage industries to which the handloom industry belongs are oriented towards balanced socio-economic development of our country owing to the built-in mechanism that encourages weavers and craftsmen to seek an honourable place in the society. Handloom industry occupies a place of importance in our country's economy chiefly by virtue of its employment potential, production and export orientations.

\section{Recent Developments}

There is a general feeling that the policies of the Government are not favourable for both handlooms and power looms. Majority of the weavers attribute their distress to the negligent intervention of the Government. Particularly the reforms introduced and the recommendations of the committees appointed were blamed as these are the main responsible factors for the downfall of weaving industry in recent years. Hence the recommendations of the latest committees and policies are summarized in the succeeding paragraphs.

\section{Abid Hussain Committee}

In 1988, a committee was appointed to analyse the problems arisen in the industry after the announcement of Textile Policy 1985, under the chairmanship of Abid Hussain. The committee submitted its report in 1990 and recommended creation of a number of new institutions, as it felt that the 1985 textile policy has failed to provide adequate institutional support to weavers.

However, it was criticized that the Seventh Plan was favourable to large scale sector and power looms. As a result, many weavers lost their jobs and during Eighth Plan there was a decline in the number of commercial handlooms by 9 lakhs from 38.9lakhs in the Seventh Plan. The subsidy under Janatha cloth rate rose to Rs.3.40 from Rs.2.75 per sq. meter from July 1990. In 1991 two new schemes were taken up, i.e., one relating to the procurement of handloom products from North East and the other relating to handloom export development.

\section{Mira Seth Committee (1995)}

The Government of India appointed high powered committee under the Chairmanship of Mira Seth in 1995 to review the performance of handloom sector in the decade since 1985. 
The committee reported that the production increased by 63.6 per cent in 1996 over 1991. The committee recommended that Integrated Handlooms Village Development and Margin Money Schemes are to be merged into package scheme. The committee opined that weavers outside the cooperative fold are to be helped by instituting National Fund with Rs.500 crores, which is to be operated by voluntary organizations.

\section{Sathyam Committee (1998)}

A 12-member committee headed by S.R. Sathyam, former secretary in the Textiles Ministry, was set up in July 1998 to suggest policy measures for making different segments of textile industry competitive in the wake of globalization. The report was submitted in four chapters. The first chapter dealt with introduction, the second chapter dealt with the weaver, the third chapter contoured the technological aspects and the fourth chapter discussed the marketing and exports of textiles. However, the report was not made public and there was heavy opposition to the recommendations of the committee, CEC, a policy watch dog criticized that lithe recommendations if accepted allows the power loom sector to poach upon certain areas reserved exclusively for the handlooms. One of the suggestions, that handloom weavers convert cone yarn into hank on their own, costs them Rs.8000 crores in the next 12 years.

\section{Independent Weavers}

Out of the total weaving population, most of them are either independent weavers or master weavers. As the corporate sector is of recent origin, it has not been able to make inroads like that of cooperative sector. Theoretically, an independent weaver performs all the functions relating to the cloth weaving alone, that is, from purchasing of raw yarn and chemical, arrangement of finance, weaving of cloth, to the marketing of the finished goods. He does not employ any outside labour as owing to lack of finance forces him to depend upon the master weaver for all practical purposes.

\section{Master Weavers}

Historically, the growth of the master weavers or the middlemen (according to function) is the after effect of the First World War. Since then they have gained considerable experience in commercial production and intelligent marketing. Master Weaver is similar to the independent weaver except for the fact that he employs labour for weaving. He advances raw materials and also cash, pays wages to the weavers on the condition that the weavers should supply him fabrics of a particular design. Weaving may be done on the looms owned and installed by the master weaver at his place or at the residence of the weaver or on the looms owned by the weaver and installed in his home.

There is another class of master weavers, who can strictly be called middlemen, as they do not engage themselves in weaving, but have concentrated more on supplying of yarn and cash and marketing of cloth. They get the finished products without incurring the establishment and other costs of looms, which is analogous to the "Domestic system" which prevailed in English textile industry before industrial revolution $^{12}$

\section{OBJECTIVES}

Keeping in view the immense importance and significance of handlooms in Chittoor district, the study focuses on the socioeconomic and working conditions of weavers with due importance attached to the economics of cloth production by handlooms. More specifically, the objectives are

1. To analyze the progress of handloom industry in Chittoor District.

2. To assess the performance of handloom units in the study area.
Sample Design

Chittoor District consists of 66 Mandals. As per the National Handloom Census 2011, since the handlooms are operating in only 16 Mandals in the district, the sample selection confined to 16 Mandals of the district. Two stage random sampling was adopted to select sample weavers. Mandal is the first stage unit of sampling and weavers is the second stage unit of sampling adopted for the study. Of the 2250 units, only 225 have been selected for the survey representing 10 per cent of the total. Among the Mandals in eastern region 129 units and western region 96 units have been selected for this study. The data related to the financial year 2016-2017.

\section{Socio-Economic Profile of the Respondents}

Status of any section of population in a society is closely connected with its economic dependence in the social deprivation. Most of the welfare programmes are linked with socioeconomic status of the beneficiary families.

\section{Age}

Age is a biological component of human personality and has its own effect on thought pattern of the individuals. The opinions and attitudes of the respondents are determined by their respective age to a greater extent. The Table-l reveals the age wise distribution of the weavers.

Table-1 Age of the Responds in the Study Area

\begin{tabular}{|c|c|c|c|c|}
\hline S. No. & Age of the Respondent & $\begin{array}{c}\text { Eastern } \\
\text { Mandals }\end{array}$ & $\begin{array}{c}\text { Western } \\
\text { Mandals }\end{array}$ & Total \\
\hline 1 & \multirow{2}{*}{$30-40$ Years } & 46 & 39 & 85 \\
\cline { 3 - 5 } & & $(35.70)$ & $(40.60)$ & $(37.80)$ \\
\hline 2 & $41-50$ Years & 44 & 40 & 84 \\
\cline { 3 - 5 } & & $(34.10)$ & $(41.70)$ & $(37.30)$ \\
\hline 3 & 50 Years and above & 39 & 17 & 56 \\
\cline { 3 - 5 } & & $(30.20)$ & $(17.70)$ & $(24.90)$ \\
\hline \multicolumn{2}{|c|}{ Total } & 129 & 96 & 225 \\
\cline { 3 - 5 } & & $(100.00)$ & $(100.00)$ & $(100.00)$ \\
\hline
\end{tabular}

Source: Primary data

Note: Figures indicate percentage to total

In the Eastern Mandals, 46 respondents (35.70\%) are $30-40$ years old, 44 respondents $(30.20 \%)$ are 151 and above years old and 39 respondents $(30.20 \%)$ are 51 and above years old. Like-wise, there 39 respondents $(40.60 \%)$ are $30-40$ years old, 40 respondents $(41.70 \%)$ are $41-50$ years old and only 17 respondents $(17.70 \%)$ are 51 and above year old in the Western Mandals. It could be concluded that 37.80 per cent of the weavers are in the age group of $30-40$ years, 37.30 per cent at the weavers are in the age group $41-50$ years and only 24.90 per cent of the weavers are above the age of 51 and above years. In the Eastern Mandals most of the respondents are 30 40 years of old and in the Western Mandals most of the respondents are $41-50$ years.

Weaving is a hereditary occupation for most of the weavers in study area. Mostly weavers in this study belong to heterogeneous casts. In the Eastern Mandals there are 1 SC $(0.8 \%), 125 \mathrm{BC}(96.90 \%)$ and $3 \mathrm{OC}(2.3 \%)$ respondents. Likewise in the Western Mandals 5 respondents each (5.2\%) belong to SC and ST communities, 73 respondents (76\%) belong to $\mathrm{BC}$ community and 13 respondents (13.5\%) belong to $\mathrm{OC}$ community. It could be concluded that 98 respondents (88\%) belong to OC, 6 respondents (27\%) belong to SC and 5 respondents belong to ST community.

Caste The caste composition of the respondents was studied and presented in the Table-2.

Table-2 Caste - Wise Social Status of the Sample Respondents \begin{tabular}{|l|l|l|l|l|}
\hline S. No. & Cast & Eastern andals & Western Mandals & Total
\end{tabular}

\begin{tabular}{|l|l|l|l|l|}
\hline 1 & \multirow{2}{*}{ S.C } & 1 & 5 & 6 \\
\cline { 3 - 5 } & & $(0.80)$ & $(5.20)$ & $(2.70)$ \\
\hline
\end{tabular}




\begin{tabular}{|l|l|l|l|l|}
\hline 2 & \multirow{2}{*}{ S.T } & 0 & 5 & 5 \\
\cline { 3 - 5 } & & $(0.00)$ & $(5.20)$ & $(2.20)$ \\
\hline 3 & \multirow{2}{*}{ B.C } & 125 & 73 & 198 \\
\cline { 3 - 5 } & & $(96.90)$ & $(76.00)$ & $(88.00)$ \\
\hline \multirow{2}{*}{4} & \multirow{2}{*}{ O.C } & 3 & 13 & 16 \\
\cline { 3 - 5 } & & $(2.30)$ & $(13.50)$ & $(7.10)$ \\
\hline \multirow{2}{*}{ Total } & 129 & 96 & 225 \\
\cline { 3 - 5 } & $(100.00)$ & $(100.00)$ & $(100.00)$ \\
\hline
\end{tabular}

Source: Primary data

Note: Figures indicate percentage to total

\section{Educational Qualifications}

Education is the most important factor in improving the technical skills of weavers. It throws light on the impact of mechanization on mass production. It is also necessary to understand and keep pace with up-to-date change in the market and technical fields. It is only through awareness, the weavers can protect themselves from the clutches of master weavers and money lenders. The education status of heads of the weaver's family in study area is presented in the Table-3.

From the table it can be deciphered that in the Eastern Mandals 54 respondents (41.9\%) are illiterates, followed by 53 respondents (41.1\%) have primary education, 18 respondents (14\%) have secondary education and only 4 respondents $(3 \%)$ have inter and above education. Likewise, in the Western Mandals, 43 respondents $(44.8 \%)$ are illiterates, 24 respondents (25\%) have secondary education, 23 respondents $(24 \%)$ have primary education and only 6 respondents (6.20) have inter and above qualification.

Table-3 Educational Qualification of the Sample Respondents

\begin{tabular}{|c|c|c|c|c|}
\hline S. No. & Education & Eastern andals & \begin{tabular}{|l|} 
Western \\
Mandals
\end{tabular} & Total \\
\hline \multirow[t]{2}{*}{1} & \multirow[t]{2}{*}{ Illiterate } & 54 & 43 & 97 \\
\hline & & $(41.90)$ & $(44.80)$ & $(43.10)$ \\
\hline \multirow[t]{2}{*}{2} & \multirow[t]{2}{*}{ Primary } & 53 & 23 & 76 \\
\hline & & $(41.10)$ & $(24.00)$ & (33.80) \\
\hline \multirow[t]{2}{*}{3} & \multirow[t]{2}{*}{ Secondary } & 18 & 24 & 42 \\
\hline & & $(14.00)$ & $(25.00)$ & (18.70) \\
\hline \multirow[t]{2}{*}{4} & \multirow[t]{2}{*}{ Inter and above } & 4 & 6 & 10 \\
\hline & & $(3.00)$ & $(6.20)$ & $(4.40)$ \\
\hline \multirow{2}{*}{\multicolumn{2}{|c|}{ Total }} & 129 & 96 & 225 \\
\hline & & $(100.00)$ & $(100.00)$ & $(100.00)$ \\
\hline
\end{tabular}

Source: Primary data

\section{Note: Figures indicate percentage to total}

Above all, it could be concluded that 97 respondents (43\%) are illiterates, 78 respondents (33.8\%) have primary education, 42 respondents (18.7\%) have secondary education and only 10 respondents have inter and above qualification. Most the respondents of Western Mandals have rather higher qualifications than Eastern Mandals.

The respondents of the study area produce different type of sarees. The details of sarees produced by the respondents of both eastern and Western Mandals are presented in the Table-4.

Table-4 Product-wise Analysis of the Sample Respondents

\begin{tabular}{|c|c|c|c|c|}
\hline S. No. & Name of the Product & $\begin{array}{c}\text { Eastern } \\
\text { Mandals }\end{array}$ & $\begin{array}{c}\text { Western } \\
\text { Mandals }\end{array}$ & Total \\
\hline 1 & \multirow{2}{*}{ Cotton sarees } & 27 & 0 & 27 \\
\cline { 3 - 5 } & & $(20.90)$ & $(0.00)$ & $(12.00)$ \\
\hline 2 & Poly cotton & 23 & 0 & 23 \\
\cline { 3 - 5 } & & $(17.80)$ & $(0.00)$ & $(10.20)$ \\
\hline 3 & Silk sarees & 79 & 96 & 175 \\
\cline { 3 - 5 } & & $(61.30)$ & $(100.00)$ & $(77.80)$ \\
\hline
\end{tabular}

\begin{tabular}{|c|c|c|c|}
\hline \multirow{2}{*}{ Total } & 129 & 96 & 225 \\
\cline { 2 - 4 } & $(100.00)$ & $(100.00)$ & $(100.00)$ \\
\hline
\end{tabular}

Source: Primary data

Note: Figures indicate percentage to total

In can be obvious from the table that in the Eastern Mandals 27 respondents $(20.90 \%)$ produced cotton sarees, 23 respondents $(17.80 \%)$ produced poly cotton sarees and 79 respondents $(61.30 \%)$ produced silk sarees, but in the Western Mandals all 96 respondents (100\%) have produced silk sarees. It could be concluded that 12.00 per cent of the weavers are producing cotton source, 10.20 per cent out the weavers are producing poly cotton and 77.80 per cent at the weavers are producing silk sarees. Moreover, in both the Mandals respondents mainly produce silk sarees.

\section{Cost of Inputs}

Loom wise

Inputs immensely play a pivotal role in the yarning of clothes as they are ingredients to the production of cloth. Of late, cost of inputs is sky-rocketed but direly need for cloth production. The details cost of inputs from 2014-15 to 2008 have been dovetailed in the Table-4. The cost of inputs in 2014-15 is minimum at Rs.21452 and maximum at 1357825 with a mean of Rs.225650.12 for the respondents of $1-4$ looms. The range is very wide between minimum and maximum cost of inputs. The mean cost of inputs is Rs.2,25,850.18 with a deviation of Rs. $2,63,660.88$ which is even more than mean input cost. The respondents of 4-10 looms have incurred minimum cost of Rs. 163160 and maximum of Rs.57,50,988 with a mean of Rs.7,61,067.58 and standard deviation is.7,82,080. The range in cost of inputs is very high land shows variation in the cost of inputs of looms. In case of the respondents who possess 10 and above looms, the minimum cost of inputs Rs.8,28,223 and the maximum of Rs.1,08,13,300 with an a average of Rs.31,35,007.6. The range is so wide due to various reasons. The deviation of that cost of inputs is $29,12,890$ which shows more variation in the cost of inputs. The results of ANOVA indicate that there are lots of variations in cost of inputs among the respondents with varied number of looms since ' $F$ ' values are very significant.

In 2015-2016, respondents of 1-4 looms incurred minimum expenditure of Rs.50133 and maximum of Rs. 2583820 with an average of Rs.345263.08 on inputs. The standard deviation is 480597. So also, 4-10 looms holding respondents have incurred minimum expenditure of Rs.2,47,500 and Rs.1,63,160 and maximum of maximum of Rs. 1846100 with an average of Rs.8,58,943.23 towards the cost of inputs. The range of between minimum and maximum is very high. Like wise, the standard deviation is 376031 which shows rather wide variation in the expenditure towards the cost of inputs. The respondents of 10 and above looms incurred an expenditure of minimum of Rs. 1020889 and maximum of Rs. 15867600 with an average of 5109272 towards the cost of inputs. The standard deviation is 4939638.18 which shows more deviation in cost of inputs. The ANOVA results indicated the F value as 74.402 which is very significant. The $F$ value infers that there are lot of variations in the expenditure incurred towards the cost of inputs by the respondents of varied looms is accepted.

In 2016-2017 the respondents of 1-4 looms have incurred minimum expenditure of Rs.72370 and maximum of Rs.1939925 with an average of Rs.596484.31 towards the cost of inputs. The range is so wide at $1 \frac{1}{2}$ folds. The value of standard deviation is Rs.5,07,886.03 which shows maximum deviation in the expenditure incurred towards the cost of inputs. Like wise the respondents of 4-10 looms have incurred expenditure minimum at Rs.311542 and maximum at Rs.7747260 with an average of Rs. 118913151 towards the cost of inputs. The standard deviation is 5459182.36 which shows yawning difference in the expenditure incurred by the respondents towards the cost of inputs. 
Table-5 Loom-wise Cost of Inputs

\begin{tabular}{|c|c|c|c|c|c|c|c|c|c|}
\hline S.No. & Variables & No. of looms & $\mathrm{N}$ & Mean & Std. Deviation & F-Value & P- Value & Minimum & Maximum \\
\hline \multirow[t]{4}{*}{1} & \multirow[t]{4}{*}{ Cost of inputs in 2014-15 } & $1-4$ & 80 & 225850.1750 & 263660.88250 & \multirow[t]{4}{*}{65.410 ** } & \multirow[t]{4}{*}{0.000} & 21452.00 & 1357825 \\
\hline & & $4-10$ & 102 & 761067.5784 & 782080.40931 & & & 163160.00 & 5750988 \\
\hline & & 10 and above & 43 & 3135007.6047 & 2912890.85208 & & & 828223.00 & 10813300 \\
\hline & & Total & 225 & 1024454.3733 & 1733691.69804 & & & \begin{tabular}{|l|}
21452.00 \\
\end{tabular} & 10813300 \\
\hline \multirow[t]{4}{*}{2} & \multirow[t]{4}{*}{ Cost of inputs in 2015-16 } & $1-4$ & 80 & 345263.0750 & 480597.52800 & \multirow[t]{4}{*}{$74.402^{* \star}$} & \multirow[t]{4}{*}{0.000} & 50133.00 & 2583820 \\
\hline & & $4-10$ & 102 & 858943.2353 & 376031.18949 & & & 247500.0 & 1846100 \\
\hline & & 10 and above & 43 & 5109272.3256 & 4939638.17646 & & & 1020889 & 15867600 \\
\hline & & Total & 225 & 1488586.5156 & 2807869.30378 & & & 50133.00 & 15867600 \\
\hline \multirow[t]{4}{*}{3} & \multirow[t]{4}{*}{ Cost of inputs in 2016-17 } & $1-4$ & 80 & 596484.3125 & 507886.03484 & \multirow[t]{4}{*}{$57.295^{* \star}$} & \multirow[t]{4}{*}{0.000} & 72370.00 & 1939925 \\
\hline & & $4-10$ & 102 & 1189131.5098 & 1374199.77035 & & & 311542.0 & 7747260 \\
\hline & & 10 and above & 43 & 5539004.1163 & 5459182.36297 & & & 1097278 & 17787900 \\
\hline & & Total & 225 & 1809721.4933 & 3146628.49456 & & & 72310.00 & 17787900 \\
\hline \multirow[t]{4}{*}{4} & \multirow[t]{4}{*}{ Cost of inputs in 2017-18 } & $1-4$ & 80 & 658271.5375 & 574589.42982 & \multirow[t]{4}{*}{$57.851^{* *}$} & \multirow[t]{4}{*}{0.000} & 76333.00 & 2167600 \\
\hline & & $4-10$ & 102 & 1292039.1471 & 1542226.92144 & & & 350320.0 & 8680200 \\
\hline & & 10 and above & 43 & 5581519.7907 & 5257335.00328 & & & 1196828 & 17910250 \\
\hline & & Total & 225 & 1886466.9644 & 3113180.54084 & & & 76333.00 & 17910250 \\
\hline
\end{tabular}

Source: Primary Data

The cost of inputs is immensely increasing over the years. During 2016-2017 respondents of 1-4-looms have incurred minimum expenditure of Rs.76,333 and maximum of Rs.21,67,600 with an average of Rs.6,58,271.54 towards the cost of inputs. The range is so wide in the expenditure incurred on the cost of inputs. More over, the standard deviation value 574589 indicates more deviation. The respondents of 4-10 looms paid minimum of Rs.3,50,320 and maximum of Rs.86,80,200 and the average of Rs.12,92,039.15 towards the cost of inputs. The range indicates lot of variation. The standard deviation is $15,42,226.92$ which indicates lot of deviation. Like wise, the respondents of 10 and above looms have spent a minimum amount of Rs.1 196828 and maximum amount of Rs.1,79,10,250 with an average of 5,58,159.79 on the cost of inputs. The range is very high the standard deviation value is $52,57,335$ which indicates higher deviation in the amounts spent on purchasing inputs which are the ingredients of yarning cloth. The ANOVA results indicate that the $F$ value is 57.851 which is very significant. It can be concluded that the amount spent on purchase of inputs is very high and net uniform.

The cost of inputs has been increased from 2014-15 to 20172018 regardless of number of looms. Moreover, higher the number of looms higher is the expenditure towards the cost of inputs. The ' $F$ ' value is significant at 1 per cent level and confirmed that there are variations in the cost of inputs among the respondents of varied number of looms.

\section{Net Income}

Net income is immensely important for the sustenance of life and devoid of it, life can't be assumed or viewed. The net income of different loom holders for 2014-15 to 2017-2018 has been subjected to descriptive statistics apart from significance test and the analysis results have been dovetailed in the Table-6.

About 80 respondents, having 1-4 looms, got minimum income of Rs.9775 and maximum income of Rs.3115000 with an average of Rs.656975.71. The deviation is 1014988.79 which indicates variation in the income levels of the respondents. In case as 4-10 loom holding respondents, the income is minimum at Rs.43,850 and maximum at 5750000 with an average of $27,05,834$. The standard deviation is $20,71,030$ which indicates random income among the respondents. The respondents of 10 and above looms have a minimum income of Rs.5,00,000 maximum of Rs.5,46,25,000 with an average income of Rs.1,07,67,666.28. The standard deviation of income is 15169322 and indicates more deviation. The ' $F$ ' test results indicate that the F value is 32.519 which is lower than the table value and indicates that higher the looms higher is the income.

In 2015-2016, the respondents of 1-4 looms generated minimum income of Rs. $1,03,250$ and maximum of $36,57,000$ with an average of Rs.95712975. There is wide rage between the minimum and the maximum income. The standard deviation value is 1957483 and shows lot of variation in the income levels of the respondents. Like wise 4-10 looms holding respondents got minimum income of Rs.3,94,450 and maximum of Rs.62,25,000 with an average of 2564285.54 . The deviation in income is at 1957483 showing much variation in the income. The respondents possessing 10 and above looms generated minimum income of Rs. 2013500 and maximum of Rs. $8,05,00,000$ with an average as Rs. $1,85,03,384.88$. The range is rather high between the minimum and the maximum and variation is also very high since the deviation is 22194321.22

The ' $F$ ' test results show that the $F$ value is 51.166 , which is lower than the taste value indicates that there is differences in income levels of respondent of varied looms.

The 1-4 loom holding respondents in 2016 - 2017 have generated minimum income of Rs. $1,05,000$ and maximum of Rs.44,73,500 with an average of Rs.101908475. The range of income is very high and shows much variation. The standard deviation is $13,56,292$ which indicates yowning gap between the income levels. The respondents of $4-10$ looms have earned minimum income of Rs.52470 and maximum income of Rs.73,60,000 with an average of Rs.3446428.51. Wide range in income is obviously observed. The value of deviation is $24,59,929.72$ and indicates variation in large in the income of respondents whereas the 4 and above looms holding respondents gained minimum income of Rs.2098750 and maximum of Rs.8,05,00,000 with an average of Rs.18,88,37,221.

Table-6 Net Income

\begin{tabular}{|c|c|c|c|c|c|c|c|c|c|}
\hline S.No. & Variables & No. of looms & $\mathbf{N}$ & Minimum & Maximum & F-Value & P- Value & Mean & Std. Deviation \\
\hline \multirow{2}{*}{1} & Net income in 2014-15 & $1-4$ & 80 & 9775.00 & 3115000 & $32.519^{* *}$ & 0.000 & 656975.7125 & 1014988.79081 \\
\cline { 3 - 10 } & & $4-10$ & 102 & 43850.00 & 5750000 & & & 2705834.7059 & 2071030.31815 \\
\cline { 3 - 10 } & & 10 and above & 43 & 500000.00 & 54625000 & & & 10767666.2791 & 15169322.68751 \\
\cline { 3 - 10 } & & Total & 225 & 9775.00 & 54625000 & & & 3518057.0978 & 7665215.73691 \\
\hline 2 & \multirow{2}{*}{ Net income in2015-16 } & $1-4$ & 80 & 103250.00 & 3657000 & $51.116^{* *}$ & 0.000 & 957129.7500 & 1144624.89413 \\
\cline { 3 - 10 } & & $4-10$ & 102 & 394450.00 & 6225000 & & & 2564285.5392 & 1957483.00196 \\
\hline
\end{tabular}




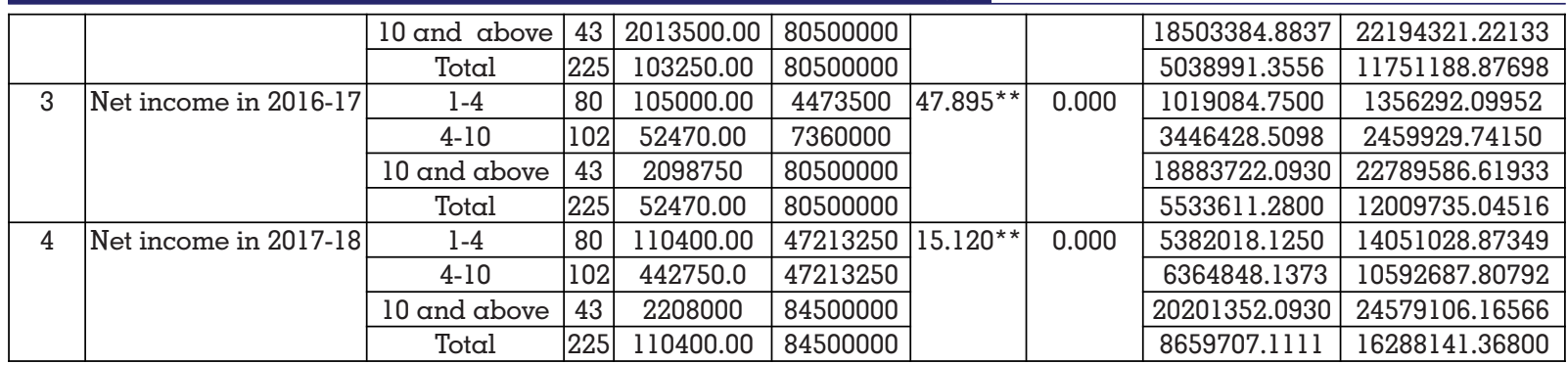

The standard deviation is $2,27,89,586.62$ which shows wide variation in the income. The ANOVA results indicates that the derived 'F' values is less that the table value and indicates that there are variations in the income of varied number loom holders.

In 2017-2018, respondents of 1-4 looms have generated maximum income of Rs.4,72,13,250 and minimum of Rs. $1,10,400$ with a mean income of Rs.53,82,018.1250. There is a yawning range between minimum and maximum income. The deviation of 10592687.81 shows lot of variation in the incomes of respondents. Likewise 4-10 looms holding respondents have obtained minimum income of Rs.44,27,450 and maximum of Rs.4,72,13,250 with an average of Rs.63,64,848.14. There is wide range in the income levels. The deviation in the income is $1,05,92,687.8$ which shows lot of variation in the income levels of the respondents of varied loom number. In case 10 and above loom holding respondents minimum income is Rs. $22,08,000$ and maximum of $8,45,00,000$ with a mean income of Rs.2,02,01,352.09. The range is so wide that the income levels are too different. The deviation is 24579106 which is more than mean and indicate much variation in the income levels of the respondents. The two ANOVA indicates the F values as 15.120 which is less than the table value. It could be concluded that higher the number of looms higher will be the income.

The net income of the respondents of $1-4$ looms and 10 and above has gradually increased, but the income is low for respondents of 4-10 looms in 2017-2018 owing to their dependency even on some other subsidiary activities which are more fetching. The income has gradually increased and higher the number of looms higher is net income.

\section{CONCLUSION}

The Indian economic development has been viewed in the light of the socio-economic factors, preservation of the traditional skills of the people and the use of the available resources. Handlooms have a great potential in this regard as they hold the key not only for sustaining the existing craft persons, but also for providing gainful employment, both fulltime and part-time, to increasingly larger sections of the economically poor and dispossessed weavers. The range is very high the standard deviation value is $52,57,335$ which indicates higher deviation in the amounts spent on purchasing inputs which are the ingredients of yarning cloth. Moreover, higher the number of looms higher is the expenditure towards the cost of inputs. The standard deviation of income is 15169322 and indicates more deviation. The deviation in income is at 1957483 showing much variation in the income. The respondents possessing 10 and above looms generated minimum income of Rs.2013500 and maximum of Rs.8,05,00,000 with an average as Rs. $1,85,03,384.88$. The range is rather high between the minimum and the maximum and variation is also very high since the deviation is 22194321.22 . The value of deviation is $24,59,929.72$ and indicates variation in large in the income of respondents whereas the 4 and above looms holding respondents gained minimum income of Rs.2098750 and maximum of Rs.8,05,00,000 with an average of Rs.18,88,37,221. The net income of the respondents of $1-4$ looms and 10 and above has gradually increased, but the income is low for respondents of 4-10 looms in 2017-2018 owing to their dependency even on some other subsidiary activities which are more fetching. The income has gradually increased and higher the number of looms higher is net income.

\section{REFERENCES:}

1. Jagadeesan S., Handloom Weaving and Employment Potential, the Cooperator, Vol.16, No.5, lst September, 1978.

2. Government of India, 'Abid Hussain Committee Report on Handloom Industry,' January 1990.

3. Jain, L.C. (1988), Textile Policy in Practice: A Balance Sheet after three years. Times of India, June 17.

4. Government of India (1997), Report of the High Powered Committee (Mira Seth Committee), New Delhi.

5. Government of India (1998), Report of the Satyam Committee, New Delhi.

6. Government of India (2000), National Textile Policy - 2000, Published in Internet File/A-NTP-2000, HTM

7. Handloom Weavers - Co-operative Support. "The Co-operator", NCUI, New Deli. VOL. XVIII, No. 5, 01.09.1980.

8. Important Items of Data Credit and Non-Credit Co-operative Societies, 1986 87, Economic Analysis Department, NABARD, Bombay.

9. Report of the Working Group on Handlooms, Ministry of Commerce, Govt. of India, 1965.

10. Agnihotri V.K., An Apology for Handlooms Productivity, 26th October, 1985. 